\title{
Effects of ensiling density on chemical and microbiological characteristics of sorghum silage
}

\author{
A.H.C. Anésio ${ }^{1}$, M.V. Santos ${ }^{1}$, L.D. da Silva ${ }^{1,4}$, R.R. Silveira', T.G.S. Braz ${ }^{2}$ and R.C. Pereira ${ }^{3}$ \\ ${ }^{1}$ Universidade Federal dos Vales do Jequitinhonha e Mucuri, Diamantina, MG, 39100-000, Brazil \\ ${ }^{2}$ Universidade Federal de Minas Gerais, Montes Claros, MG, 39404-547, Brazil \\ ${ }^{3}$ Instituto Federal de Educação, Ciência e Tecnologia Fluminense, Bom Jesus do Itabapoana, RJ, 28300-000, Brazil
}

KEY WORDS: Sorghum bicolor silage, dry matter loss, lactic acid bacteria

Received: 25 November 2016

Revised: 14 February 2017

Accepted: 9 March 2017

${ }^{4}$ Corresponding author:

e-mail: leandrodiegodasilva@gmail.com

\begin{abstract}
The aim of the study was to evaluate the effect of ensiling density on chemical and microbiological characteristics of sorghum silage. Thirty-six minisilos made of PVC with a volume of $3.1 \mathrm{dm}^{3}$ were used. A completely randomized design was used with six replications per each treatment. The treatments differed in packing density: $300,375,450,525,600$ and $675 \mathrm{~kg}$ of fresh forage per $\mathrm{m}^{3}$. The contents of dry matter (DM), crude protein and the count of lactic acid bacteria tended to increase with increasing packing density. The highest DM contents were observed for silages with density of $525 \mathrm{~kg} \cdot \mathrm{m}^{-3}$. The contents of organic matter, water-soluble carbohydrates, ammonia nitrogen, acid detergent fibre, hemicellulose, cellulose and nitrogen insoluble in neutral and acid detergents were not affected by silage density. However, the contents of neutral detergent fibre, lignin, $\mathrm{pH}$ values, yeast and mould counts and the DM losses tended to decrease together with increasing silage density. It was observed that the silage with the highest density resulted in lower DM losses when compared to the silage densities lower than $525 \mathrm{~kg} \cdot \mathrm{m}^{-3}$. So, it can be stated that the minimum density of sorghum silage ensuring its quality is $525 \mathrm{~kg} \cdot \mathrm{m}^{-3}$.
\end{abstract}

\section{Introduction}

Sorghum silage is an excellent energy source for all ruminant species. Like maize, sorghum plants have great production potential and desirable characteristics to produce high quality silage: appropriate dry matter (DM) content, high content of water-soluble carbohydrates (WSC) and low buffer capacity at the harvest time. Furthermore, sorghum with lower than maize sensibility to water deficit, has become an interesting option for arid and semiarid regions in the world (Getachew et al., 2016).

However, during the ensiling process, large amount of oxygen is produced inside the silo. This results in increased survival of undesirable microorganisms, such as, aerobic bacteria and fungi that compete with lactic acid bacteria (LAB) for the soluble carbohydrates, thus damaging the $\mathrm{pH}$ reduction and the feed preservation. So, oxygen is undesirable factor to obtain a high-quality silage. Therefore, the compression of forage at ensiling is needed to reduce the amount of oxygen and in consequence improve the final quality of silage. High silage densities promote the elimination of oxygen and ensure anaerobic conditions inside the silo. In addition, increased capacity of the silo and reduced spoilage has another pros - reduced cost of storage (Pahlow et al., 2003; Sucu et al., 2016). 
Based on the hypothesis that there is a minimum density required to ensure the preservation of the quality of sorghum silage, the aim of the study was to examine the effect of packing density on the chemical and microbiological characteristics of sorghum silage.

\section{Material and methods}

The sorghum (Sorghum bicolor (L.) Moench) hybrid BRS655 was sown in December 2013, in Couto de Magalhes de Minas area, Minas Gerais (Brazil; $18^{\circ} 4^{\prime}$ south latitude and $43^{\circ} 28^{\prime}$ west longitude) at $733 \mathrm{~m}$ above the sea level. The climate of this region is humid subtropical (Cwa) according to the climatic classification of Köppen-Geiger. The sowing method: $0.9 \mathrm{~m}$ of row spacing and 11 viable seeds per metre was used, with the final population of approximately 120 thousand plants $\mathrm{ha}^{-1}$. Simultaneously, $300 \mathrm{~kg} \cdot \mathrm{ha}^{-1}$ of formulated fertilizer 8-28-16 ( $\left.-\mathrm{N}_{2} \mathrm{O}_{5}-\mathrm{K}_{2} \mathrm{O}\right)$ were applied.

120 days after sowing, when the grain reached the hard-dough stage, the sorghum plants were harvested by hand at $10 \mathrm{~cm}$ from ground level. The harvested forage was chopped into a theoretical particle length of $2 \mathrm{~cm}$ by using a forage harvester JF-92 Z10 (JF Agricultural Machinery, São Paulo, Brazil). A sample of fresh forage before ensiling was stored at $0{ }^{\circ} \mathrm{C}$ for subsequent analysis of DM, WSC and crude protein $(\mathrm{CP})$. The chemical composition of the sorghum before ensiling was: DM $-35.9 \%$ fresh matter, WSC $-19.3 \% \mathrm{DM}$ and $\mathrm{CP}-8.83 \% \mathrm{DM}$.

Thirty-six mini-silos made of PVC with a volume of $3.1 \mathrm{dm}^{3}$ (length $400 \mathrm{~mm}$ and diameter $100 \mathrm{~mm}$; Tigre, Joinville, Brazil) were used. A completely randomized design with six replications of each treatment was used. The treatments differed in packing densities: 300, 375, 450, 525, 600 and $675 \mathrm{~kg}$ of fresh forage per $\mathrm{m}^{3}(108,135,162,188$, 215 and $242 \mathrm{~kg}$ of $\mathrm{DM} \cdot \mathrm{m}^{-3}$, respectively). The lowest density was defined as the amount of forage placed inside the mini-silo until filling, without compression ( $0.96 \mathrm{~kg}$ of fresh forage). The highest density was obtained when the forage was placed inside the mini-silo until filling with the maximum possible compression (2.90 kg of fresh forage). The corresponding amount of forage for each treatment was weighed on a precision scale and the manual compression was performed using wooden sockets. After complete filling, the top of the minisilo was sealed with a PVC cover containing Bunsen valve which allowed gas to move out. The mini-silos were kept in a covered and airy room at mean environmental temperature of $26^{\circ} \mathrm{C}$.

After 95 days of ensiling, all mini-silos were weighed and opened. After discarding the first $5 \mathrm{~cm}$ of silage (surface layer), the silage in each mini-silo was homogenized and split into 3 portions.

Immediately after the mini-silo opening, the first portion was used for microbiological analysis. Twenty-five grams of fresh silage was homogenized in a blender with $225 \mathrm{ml}$ of sterilized saline solution ( $8.5 \mathrm{~g} \mathrm{NaCl} \cdot 1^{-1}$ of distilled water). Ten $\mathrm{ml}$ of the aqueous extract was taken for serial dilution $\left(10^{-2}\right.$ to $\left.10^{-8}\right)$. For LAB counting, the medium of Lactobacilli MRS agar (Difco, São Paulo, Brazil) was used and the plates were incubated at $35^{\circ} \mathrm{C}$ for $72 \mathrm{~h}$. For quantifying moulds and yeasts, the medium of potato dextrose agar (PDA; Difco, São Paulo, Brazil) was incubated at $25{ }^{\circ} \mathrm{C}$ for $72 \mathrm{~h}$. For data analysis of microorganisms quantification, the counts were transformed into $\log _{10}$ of colony forming unit (CFU) $\cdot \mathrm{g}^{-1}$.

The second portion of approximately $150 \mathrm{~g}$ of fresh silage was dried at $60{ }^{\circ} \mathrm{C}$ for $72 \mathrm{~h}$ in a forced air oven, ground in a Wiley mill with a $1-\mathrm{mm}$ screen and stored in plastic containers for the determination of DM (method 934.01; AOAC, 1990). Organic matter $(\mathrm{OM})$ was determined as DM - ash (method 924.05; AOAC, 1990). CP was calculated by determining total $\mathrm{N}$ using the micro-Kjeldhal procedure (method 920.87; AOAC, 1990) and using a fixed conversion factor (6.25). The following parameters were also measured: neutral detergent fibre (NDF; Mertens, 2002), acid detergent fibre (ADF; method 973.18; AOAC, 1990) and lignin through cellulose solubilization with sulphuric acid (Robertson and Van Soest, 1981). The NDF and ADF contents were corrected for protein according to Licitra et al. (1996). The hemicellulose was calculated as NDF - ADF, and the cellulose as ADF - lignin residue after treatment with sulphuric acid.

The third portion of samples was pressed $(\sim 100 \mathrm{kPa})$ in a hydraulic press and $200 \mathrm{ml}$ of the extract was collected for subsequent analysis of ammonia nitrogen concentration $\left(\mathrm{NH}_{3}-\mathrm{N}\right.$; Licitra et al., 1996), WSC (DuBois et al., 1956) and pH.

The $\mathrm{pH}$ was measured by using a $\mathrm{pH}$ meter (Tecnal, São Paulo, Brazil).

The DM loss was determined as the difference between initial and final weights (DM basis) of mini-silos, in relation to the amount of DM forage ensiled.

The data were subjected to one way analysis of variance and the means were compared by the 
Tukey's post-hoc test with 5\% of probability. All statistical analyses were performed by using the SAS 9.0 (2002; SAS Institute, Cary, NC, USA).

\section{Results}

The silage density affected the final content of DM. The highest DM contents were observed for silages with density of $525 \mathrm{~kg} \cdot \mathrm{m}^{-3}(P=0.025$; Table 1). However, the OM and WSC contents were not affected by silage density $(P>0.050)$.

The CP concentration tended to increase with increasing silage density $(P=0.003)$. The $\mathrm{CP}$ concentration was higher in the silages with densities of 600 and $675 \mathrm{~kg} \cdot \mathrm{m}^{-3}$ in comparison to the silage with density of $300 \mathrm{~kg} \cdot \mathrm{m}^{-3}$. However, the silage density had no effect on the ammonia nitrogen concentration $(P=0.149)$.

The NDF concentration tended to decrease as the silage density increased $(P=0.007)$. Nevertheless, there were observed no effects of silage density

Table 1. Chemical and microbiological characteristics of sorghum silage with different densities

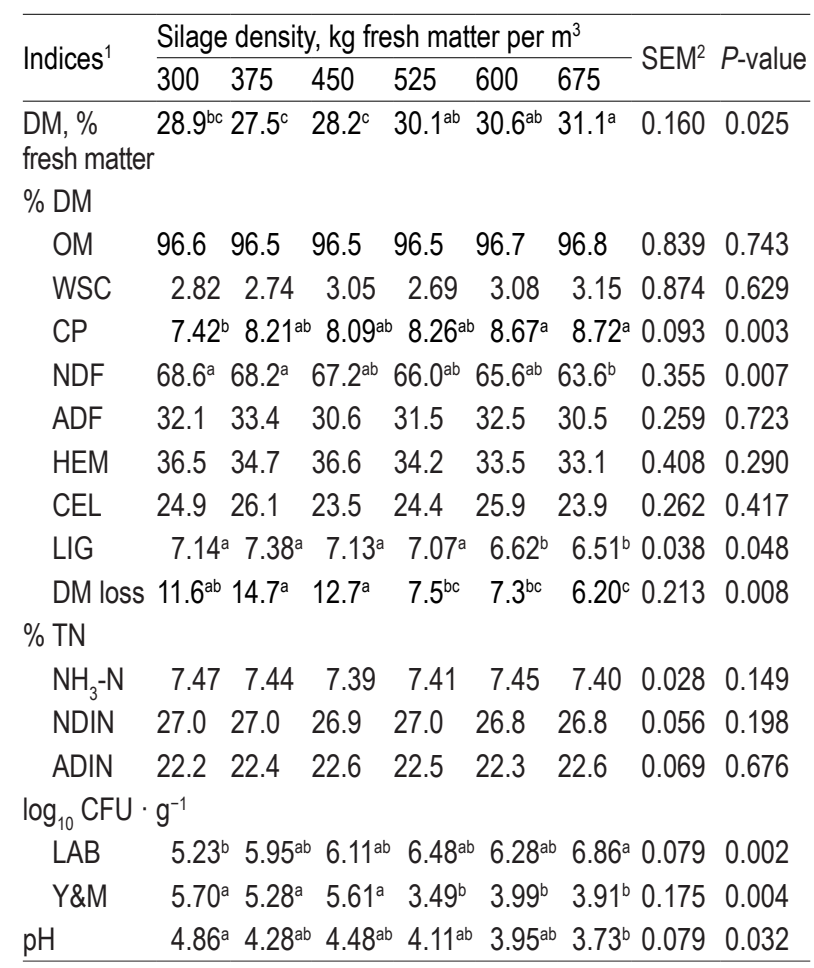

${ }_{1}^{1}$ DM - dry matter; OM - organic matter; WSC - water-soluble carbohydrates; CP - crude protein; NDF - neutral detergent fibre; ADF - acid detergent fibre; HEM - hemicellulose; CEL - cellulose; LIG - lignin; DM loss - dry matter loss; TN - total nitrogen; $\mathrm{NH}_{3}-\mathrm{N}$ - ammonia nitrogen; NDIN - neutral detergent insoluble nitrogen; ADIN - acid detergent insoluble nitrogen; CFU - colony forming unit; $L A B$ - count of lactic acid bacteria; $Y \& M$ - count of yeast and mould; ${ }^{2} \mathrm{SEM}$ - standard error of mean; abc - means with different superscripts within each row are significantly different according to Tukey's test at $5 \%$ of probability on the ADF, HEM and cellulose concentrations $(P>0.050)$. The lignin content tended to decrease with increasing silage density $(P=0.048)$. The content of neutral detergent insoluble nitrogen (NDIN) and acid detergent insoluble nitrogen (ADIN) were not affected by the silage density $(P>0.05)$, with averages of 27.0 and $22.9 \%$ of total nitrogen, respectively.

The $\mathrm{pH}$ values tended to decrease along with increasing silage density $(P=0.032)$ and the statistical difference was observed between silages with density of 300 and $675 \mathrm{~kg} \cdot \mathrm{m}^{-3}$. The LAB counts tended to increase together with increasing silage density $(P=0.002)$. The silages with density of 300 and $675 \mathrm{~kg} \cdot \mathrm{m}^{-3}$ resulted in the lowest and highest values of $\mathrm{LAB}$ population, respectively. In addition, the number of moulds and yeasts tended to decrease with increasing silage density $(P=0.004)$. The lowest mould and yeast counts were observed from the silage with density of $525 \mathrm{~kg} \cdot \mathrm{m}^{-3}$.

The DM losses tended to decrease with an increasing silage density $(P=0.008)$. It was observed that the silage with the highest density $\left(675 \mathrm{~kg} \cdot \mathrm{m}^{-3}\right)$ resulted in lower DM loss in comparison to the silages with density lower than $525 \mathrm{~kg} \cdot \mathrm{m}^{-3}$.

\section{Discussion}

The reduction on the DM content of roughage during the fermentation process in the silo is connected with the decrease in cellular content - the effect of WSC consumption by plant, microbial respiration and spoilage (McDonald et al., 1991). According to Ruppel et al. (1995), the compression directly affects the silage oxygen concentration and thus the respiration extent of plant tissues and aerobic microorganisms. Therefore, the higher respiratory losses are dependent on the amount of oxygen, and result in lower content of WSC to LAB fermentation. Thus, the silages with lower densities had probably greater degradation level.

However, in the present study, the WSC concentration was the variable analysed with the highest variation, probably because of this significant difference between the treatments was not observed, despite of $11 \%$ difference on the WSC concentration between the lowest and highest silage density.

Higher silage densities, up to a certain limit, guarantee the preservation of the silage with a better nutritional quality. In our study, the highest CP concentration with higher silage densities may be related to the DM loss, since that the silage density had no effect on ammonia nitrogen concentration. 
Silage with low packing density is characterized by crop respiration and activity of all obligatory and facultative aerobic organisms such as moulds, yeasts and some bacteria that consume sugars and protein to grow and as a consequence release gas and heat. In addition, the conversion of WSC into other compounds other than lactic acid can damage the efficiency of fermentation process by keeping high pH (Pahlow et al., 2003). However, Velho et al. (2007) evaluated the maize silage with density of 500 and $600 \mathrm{~kg}$ of fresh forage per $\mathrm{m}^{3}$, and did not observed any effects on $\mathrm{CP}$ concentrations.

During ensiling the cell content is fermented by microorganisms. When the fermentation is longer the excessive consumption of cell content results in increased cell wall concentration, which is practically not used in the silage fermentation (Pahlow et al., 2003). In our study the lower lignin content, as well as NDF concentration, were connected with lower losses of cell content, mainly WSC and CP that were better preserved in silages with the highest densities.

The NIDIN and ADIN values for sorghum forage in the 'Brazilian Table of Food Composition for Cattle' were 39.8 and $21.8 \%$ total nitrogen, respectively (Valadares Filho et al., 2016). The NDIN concentrations in our study are below those reported in the 'Brazilian Table of Food Composition for Cattle' probably due to the characteristics of the sorghum cultivar and presence of tannin (Gxasheka et al., 2015). In addition, despite different silage densities, probably no excessive heating occurred during the fermentation to cause an increase in NDIN or ADIN values.

The proper density provide an anaerobic environment that is conducive to the $\mathrm{LAB}$ development resulting in increased lactic acid production and, consequently, lower pH (Pahlow et al., 2003; Sucu et al., 2016). The $\mathrm{pH}$ and the ammonia nitrogen are parameters that help to define a good silage fermentation, because are related to the acceptability of silage by the animals (Pahlow et al., 2003). Sucu et al. (2016) in a study with sorghum silage with two densities (132 and $178 \mathrm{~kg} \cdot \mathrm{m}^{-3}$ of DM) after 60 days of ensiling observed that the silage with higher density showed higher WSC and CP contents and, consequently, lower DM losses (although no difference observed in the $\mathrm{pH}$ level). The $\mathrm{pH}$ values from 3.8 to 4.2 are expected in a well-preserved silage. However, mainly the decreased rate of $\mathrm{pH}$ and the final $\mathrm{pH}$ of the fermentation are the characteristics that will determine which microorganisms are capable to grow and predominate in the silage (McDonald et al., 1991).
The anaerobic conditions inside the silo with higher density favour the growth of bacteria mainly of the Lactobacillus genus. On the other hand, the silage with low density favours the development of mould and yeasts due to the higher concentration of oxygen inside the silo (Pahlow et al., 2003). Woolford (1990) noted that the silages that showed count of yeasts greater than $5.0 \log _{10} \mathrm{CFU} \cdot \mathrm{g}^{-1}$ are more susceptible to deterioration. This may explain the worst characteristics observed in our study for the silages with lower densities - at the time of the silo opening these silages were blackened with a strong odour, and moulds and yeasts content was $5.70 \log _{10} \mathrm{CFU} \cdot \mathrm{g}^{-1}$. The lower densities enable greater concentration of oxygen inside the silo complicating the LAB predominance and $\mathrm{pH}$ reduction (Pahlow et al., 2003). Therefore, an extensive fermentation probably occurs in the low silage density, and fermentation by undesirable bacteria and aerobic deterioration results in greater DM loss.

Practically, the packing time and tractor weight are the most important factors related to silage density (Ruppel et al., 1995). In addition, it is necessary to know the capacity of the silo to determine the minimum amount of forage that should be placed in the silo to ensure a good density (Muck and Holmes, 2000).

\section{Conclusions}

The higher density of silage allow greater conservation of sorghum silage nutrients. The minimum density to ensure the quality of sorghum silage is $525 \mathrm{~kg}$ of fresh matter per $\mathrm{m}^{3}(188 \mathrm{~kg}$ of DM per $\mathrm{m}^{3}$ ).

\section{Acknowledgements}

We would like to thank the Coordenação de Aperfeiçoamento de Pessoal de Nível Superior (CAPES), the Conselho Nacional de Desenvolvimento Científico e Tecnológico (CNPq) and the Fundação de Amparo à Pesquisa do Estado de Minas Gerais (FAPEMIG) for the financial support.

\section{References}

AOAC, 1990. Official Methods of Analysis of the Association of Official Analytical Chemists. $15^{\text {th }}$ Edition. Arlington, VA (USA)

DuBois M., Gilles K.A., Hamilton J.K., Rebers P.A., Smith F., 1956. Colorometric method for determination of sugars and related substances. Anal. Chem. 28, 350-356, https://doi. org/10.1021/ac60111a017 
Getachew G., Putnam D.H., De Ben C.M., De Peters E.J., 2016. Potential of sorghum as an alternative to corn forage Am. J. Plant. Sci. 7, 1106-1121, https://doi.org/10.4236/ ajps.2016.77106

Gxasheka M., Tyasi T.L., Qin N., Lyu Z.-C., 2015. An overview of tannins rich plants as alternative supplementation on ruminant animals: A Review. Int. J. Agric. Res. Rev. 3, 343-349

Licitra G., Hernandez T.M., Van Soest P.J., 1996. Standardization of procedures for nitrogen fractionation of ruminant feeds. Anim. Feed Sci. Technol. 57, 347-358, https://doi.org/10.1016/03778401(95)00837-3

McDonald P., Henderson A.R., Heron S.J.E. (Editors), 1991. The Biochemistry of Silage. $2^{\text {nd }}$ Edition. Chalcombe Publications. Mallow, Bucks (UK), https://doi.org/10.1017/ S0014479700023115

Mertens D.R., 2002. Gravimetric determination of amylase-treated neutral detergent fibre in feeds with refluxing in beaker or crucibles: collaborative study. J. AOAC Int. 85, 1217-1240

Muck R.E., Holmes B.J., 2000. Factors affecting bunker silo densities. Appl. Eng. Agric. 16, 613-619, https://doi. org/10.13031/2013.5374

Pahlow G., Muck R.E., Driehuis F., Oude Elferink S.J.W.H., Spoelstra S.F., 2003. Microbiology of ensiling. In: D.R. Buxton, R.E. Muck, J.H. Harrison (Editors). Silage Science and Technology. American Society of Agronomy, Inc, Crop Science Society of America, Inc., Soil Science Society of America, Inc. Publishers. Madison, WI (USA), pp. 31-94
Robertson J.B., Van Soest P.J., 1981. The detergent system of analysis and its application to human foods. In: W.P.T. James, 0 . Theander (Editors). The analysis of dietary fibre in food. Marcel Dekker. New York, NY (USA), pp. 123-158

Ruppel K.A., Pitt R.E., Chase L.E., Galton D.M., 1995. Bunker silo management and its relationship to forage preservation on dairy farms. J. Dairy Sci. 78, 141-153, https://doi.org/10.3168/ jds.S0022-0302(95)76624-3

Sucu E., Kalkan H., Canbolat O., Filya I., 2016. Effects of ensiling density on nutritive value of maize and sorghum silages. R. Bras. Zootec. 45, 596-603, https://doi.org/10.1590/S180692902016001000003

Valadares Filho S.C., Machado P.A.S., Chizzotti M.L., Amaral H.F., Magalhães K.A., Rocha V.R. Jr., Capelle E.R., 2016. Table of Food Composition for Cattle - CQBAL 3.0. Available on www. ufv.br/cqbal (Accessed on February 05, 2017)

Velho J.P., Mühlbach P.R.F., Nörnberg J.L., Velho I.M.P.H., Genro T.C.M., Kessler J. D., 2007. Chemical composition of maize silages with different packing densities (in Portuguese). R. Bras. Zootec. 36, 1532-1538, https://doi.org/10.1590/ S1516-35982007000700011

Woolford M.K., 1990. The detrimental effects of air on silage. J.Appl. Bacteriol. 68, 101-116, https://doi.org/10.1111/j.1365-2672.1990. tb02554.x 